\title{
Creating English Student Book Through Project Based Learning in TEYL Subject
}

\author{
Diani Nurhajati \\ University of Nusantara PGRI \\ Kediri, Indonesia \\ dianihamzah@unpkediri.ac.id
}

\begin{abstract}
Teaching English to Young Learners (TEYL) is not new in Indonesia. Many elementary schools provide English as an extra subject. The schools which apply this program must provide the facilities, such as the English teacher, the curriculum, the instructional materials, etc. because the government does not provide the guidelines which usually can be found in the content standard. This is a challenge for English Department students of teacher training college to facilitate them with knowledge and skills in TEYL. They include how to plan, how to select the material, how to teach, and how to evaluate.Therefore, this study aims at answering the questions: 1) How is the application of Project Based Learning to create English student Book in TEYL subject at University of Nusantara PGRI Kediri? and 2) How is the results of the application of Project Based Learning to create English student book in TEYL subject at University of Nusantara PGRI Kediri? This is the application of Lesson Study to improve the quality of teaching learning process in TEYL subject. It employed the following steps: Plan, Do, and See. To carry out the study, the writer worked with a lecturer and a student as the observers. The results show that Project Based Learning can help the students of Nusantara PGRI Kediri not only create English Student Book but also make a plan of TEYL, and select the materials as well as the appropriate techniques.
\end{abstract}

Keywords - Project Based Learning, English Student Book, TEYL Subject

\section{INTRODUCTION}

Nowadays English becomes an extra subject which is introduced to elementary school students in many areas. The schools which implement this program have to provide the facilities, such as the English teacher, the curriculum, the instructional materials, etc. because the government does not provide the guidelines which usually can be found in the content standard.

In fact teaching English to elementary school age students is different from the one to adult learners for some reasons. They have just got English subject for the first time. This language is rarely used in everyday communication. Besides, as young learners, they have unique characteristics which English teacher have to understand in order to implement this program successfully. Some of their characters are: they are active physically, and they have high curiosity. The ideas are supported by [1] who states that young learners learn through experience and activity. They have strong instinct from birth to explore the world. They are best seeker and player because they learn everything with by playing something. As a result, to implement English subject at elementary school level must be well prepared.

Teaching English to elementary school students is not as easy as people think. The teacher should understand children's characteristics, needs, motivation of learning English, etc. Reference [2] differs the differences between teaching a foreign language to young and adult learners. The first learners are often more enthusiastic and lively as learners. They will have a go at an activity even when they do not quite understand why or how. Furthermore, young learners do not why they have to study English. They study this language because the school provides this subject, and they have to follow the program from the school. In other words, English teachers should have special knowledge and skills if they want to teach this subject.

Next, talking about the application of teaching English at elementary school, the government does not provide the guideline for the instruction which is usually included in Content Standard. Therefore, elementary schools which apply this program must support the requirements, such as competent English teachers, course books, media, etc.

Realizing the facts, University of Nusantara PGRI Kediri provides a subject which is called Teaching English to Young Learners (TEYL) for the students in order to equip them with the knowledge and skills to implement TEYL. The goal of this subject is: "Students are able to understand the concept of TEYL as well as to design and demonstrate English subject for young learners based on the theories in Second Language Acquisition (SLA) and Teaching English as a Foreign Language (TEFL)". This subject can be programmed by the students after they take some subjects relate with teaching methodology, such as Curriculum and Material Development, Teaching English as Foreign Language 
(TEFL), and Language Assessment. To prove that the students are able to design the English subject for young learners, they have to create a product that is an English student book for young learners.

The product that the students have to create is English student book. It is a course book used by the students to study English in the classroom. This book is very important, especially for the Indonesian students and teachers. Reference [3] says that course-books can have numerous roles in foreign language teaching and might be used for presenting language material, providing learners with a wide range of activities, providing learners with grammatical rules and exercises, vocabulary and phonetic transcriptions; they can also stand for a given syllabus; they can instigate autonomous learning; they may be considered as a set of guidelines along which young, inexperienced teachers can manage their lessons. Thus, the students book created in this subject consist of various activities for practicing how to communicate English in school context.

To reach the goal, the lecturer of this subject applied Project Based Learning (PBL). According to Strippling et al. (2009, p.8) Project-based learning is the instructional strategy of empowering learners to pursue content knowledge on their own and demonstrate their new understandings through a variety of presentation modes. The students have to work together in groups and follow some steps to create a project that is the English Student Book. In sum, it can be said that project based learning facilitates students to construct knowledge by producing the product based on their interest and individual differences.

PBL is suitable with the goal as stated by [4] who provides opportunities for students to build some qualities (problem solver, responsible, works well with others, can work independently, critical thinker, confident, manages time and work effectively, and communicates well with a variety of people), as well as more deeply learn traditional academic content and understand how it applies to the real world. Meanwhile [5] states that PBL refers to student's designing, planning, and carrying out an extended project that produces a publicly-exhibited output such as a product, publication, or presentation. In short, PBL is chosen as the teaching model in TEYL as it helps students to reach the goal.

There some steps in conducting PBL in the classroom. According to [6], the steps are: 1) speculation, is teachers provide the choice of project topics initially based on curriculum and syllabus then discuss together with the students; 2) designing the project activities or planning, which refers how to organise a project activity that includes group formation, role assigning, concerning methodology decision, information source, etc.; 3) conducting the project activities, conducting the project activities in which the students work what had been planned and designed in the previous step. At this moment, the students gather information, discuss it with their group member, consult problems encountered with their teacher, and exhibit their final products in form of role play; 4) evaluation or giving feedback referring to ". It means that giving feedback and the evaluation towards the project organization, problems encountered during the process of working, student's attitudes also includes evaluation from others and self-evaluation.

Considering those facts, this study was carried out to answer the following questions: 1) how is the application of PBL to create English student Book in TEYL subject at University of Nusantara PGRI Kediri?, and 2) how are the results of the application of Project Based Learning to create English student book in TEYL subject at University of Nusantara PGRI Kediri?

\section{THE METHOD}

This study employed Lesson Study (LS) which was carried out at the English Department, University of Nusantara PGRI Kediri. The implementation of Lesson Study involved two English lecturers and one student. One lecturer played a role as the model lecturer and the other one as the collaborator who observed and gave feedback to the application of TEYL with the student. They worked collaboratively for each session that starts from defining the objectives of the teaching up to the reflection.

According to [7] there are three steps in implementing LS: plan, do, and see. The first step is plan in which the lecturers discussed and specify learning objectives appropriate to the students. They evaluated the existing syllabus and lesson plan, especially the learning outcome and the teaching objectives as well as the learning activities. They analyzed the compatible of the teaching objective and the materials used for teaching. The materials should be in line with the teaching objectives and the students can follow the lesson easily. They also collaboratively revised a complete lesson plan for teaching. The sequence of the learning activity was revised as followed: introducing the theories which support the application of TEYL, designing the lesson, formulating the goal of TEYL, selecting the materials, selecting the appropriate teaching techniques, and book designing.

The next step is do. In this step the model lecturer used the revised syllabus and lesson plan as guidance to teach in the classroom. She implemented the teaching process and the other lecturer and the student worked together to monitor and make notes for evaluation. They played role as collaborators to observe the teaching process by using observation check lists and a field note. Questionnaires were given to the students in order to collect information about their perception on the learning process of TEYL subject. The last step is see, the model lecturers and the collaborators made reflection on the application and discussed to see the strength and weaknesses of the process so that changes could be made to improve the plan for the next step. The steps above were done repeatedly in one semester. At the end of the semester, the students who took TEYL subject had to submit the product which was analyzed based on the 
integrated and graded materials, the appropriateness of the materials with the students' ability, and the attractiveness of the activities.

\section{FINDING AND DISCUSSION}

In this part it will be presented the finding of the study and discussion. Firstly, the application of PBL to create English Student Book followed the steps: speculation, designing the project activities or planning, conducting the project activities, and evaluation.

\section{Speculation}

Based on the revised syllabus and lesson plans the model lecturer introduced the plan of TEYL subject for one semester which was written in the lecture agreement. She discussed with the students the goal of the subject and the project which was going to be produced in the first meeting. She also informed the references which could be used to support in creating the book. The students were asked to make groups of three or four students. These groups worked together for one semester to create one chapter which would be compiled as a book chapter at the end of the period.

\section{Planning}

It is designing the project activity. Before designing the product, the students were assigned to get information dealing with the theories of TEYL. Some groups gave presentations on certain topics: characteristics of young learners, Second Language Acquisition theory, and teaching methods which are suitable with young learners. After the presentation they discussed those theories as the basis of the application TEYL. They also analyzed the content standard in 2006 English curriculum. After they had got the knowledge of TEYL, they designed the product. This second phase was carried for four meetings.

\section{Conducting the project}

There were some steps in conducting the project activities. First, the lecturer gave the model of product that they had to make. It was done in the sixth meeting. They analyzed the content of the model. After they had understood how to formulate learning outcomes, they had to decide the indicators, select the appropriate materials and teaching techniques. In the following meeting, they were assigned to search the information from various sources, and discussed with their group members. They could consult problems encountered with the lecturer.

\section{Evaluation}

After that, they made a draft, they did peer teaching and displayed their draft of the final products in front of the class. This activity is meant to get the evaluation from the peers and the lecturer. The lecturer gave feedback and the evaluation towards the project organization, problems encountered during the process of working, student's attitudes also includes evaluation from others and self-evaluation. This phase was carried out in five meetings. After they had got the feedback, they revised the draft and designed the lay-out of the book. Finally, they printed the book and submitted to the lecturer as the final product.

PBL is a teaching model which is appropriate for subjects which goal is creating products. Through this model the students have various learning experience which build their quality, such as cooperation, creativity, and critical thinking. Besides, this study aims at improving the quality teaching process in TEYL subject, so the TEYL lecturer worked together with other lecturer and student to apply Lesson Study. Therefore, implementing Lesson Plan is the right choice. This idea is supported by [7] who stated that Lesson Study is one of models to improve students' ability and teacher profession through learning community. This model has been applied by [8] to enhance students' self-confidence by changing the behavior of the lecturer.

The second problem in this study deals with the product which was made by the students. The product is English student book which consists of two parts. There are ten chapters for two semesters. The first part is student activity of four language skills (listening, speaking, reading, and writing). Each chapter has one theme, for examples in the classroom, at home, in the school canteen, in the school yard, etc. based on those themes, there some indicators for each skill that must be reached. The second part of the book is guidance for English teachers. By providing the guidance it is hoped that the English teachers can understand and apply the activity easily.

The final product was done by groups of students each of which had an obligation to choose teaching objective, materials, and activity as well as teacher guidance. Each group could choose the themes which learners like and they had to follow a certain format made by the lecturer. They had to develop the materials based on the themes and create an activity to learn all the language skills.

To create teaching activities they should considered some aspects: what competence and how to reach the competence. Here are the considerations:

1. The competence. In this part the students had to write the indicators of the competence; for examples, for listening skill, the students are expected able to comprehend simple instructions. The indicators of that competence are that students can identify, differ, choose the correct answer, perform something, etc. For speaking skill, they are expected to be able to express certain ideas, such as greeting, asking for help, expressing compliment, etc. The indicators must be suitable with the materials and the situations in which the language is used.

2. Materials. Based on the indicators, the students have to develop materials. They also have to write in the book the topic, the name of the game, types of activity (pairing, grouping, or classical). They also 
give example of media to support the activity, such as pictures, game boards, or even dice.

3. The procedure. It is the steps of the activity. The students have to write how to carry out the games and some notes for the rules of the game.

After each group had the design of the activity in a draft, they had to perform in the classroom in order to get feedback from the lecturer and other students. After that they had to revise and made the compilation become a book called English Student Book.

The English Student Book has been designed in order to fulfill the requirement of good book. They considered the ability of the users (elementary school students) and the curriculum, the compatible between the competence, indicators, material for all the skills. Besides, they had to make sure that the activity they provided is interesting. The learning experience can be performed in the classroom and easily organized by teacher. Those requirement are in line with [10] who stated that when teachers starting to design and develop learning materials for their learners, there are six key factors to take account. These six factors consist of learners, curriculum and context, resources and facilities, personal confidence and competence, copyright compliance, and time.

\section{CONCLUSION}

PBL is a teaching model which build students' characters; they are problem solver, responsible, works well with others, can work independently, critical thinker, confident, manages time and work effectively, and communicates well with a variety of people. By applying this model for TEYL, the students are able to create English Student Book as the final product. From the present study it can be concluded that the steps of conducting Project Based Learning are planning, resourcing, developing, and revising. The students worked in groups to create the book. The content of the final product has been tried out to know whether the activity can be applied easily by other teachers.

From the conclusion above, it is suggested for other lecturers or teachers to implement Project Based Learning in order to facilitate students with various activities to create a product, e.g. teaching speaking and teaching writing. They can adapt the steps if it is needed. For other researchers, they can compare this teaching model with other models.

\section{ACKNOWLEDGEMENT}

I dedicate this article to education in my country, especially in my hometown. Hopefully, it will inspire other lecturers or teachers that they should choose various activities in teacher in order to make students creative and have critical thinking. I would like to thank all my colleagues and my student who participate in this learning community. Special thanks go to all of my special students who create English Student Book

\section{REFERENCES}

[1] J. Moon, Children Learning English. Oxford: Macmillan Education, 2005.

[2] L. Cameron, 2001. Teaching Languages to Young Learners. United Kingdom: Cambridge University Press, 2001.

[3] J. Sárosdy, APPLIED LINGUISTICS I: for BA Students in English. Bölcsész Konzorcium. Minden jog fenntartva!c 2006.

[4] J. Larmer, J. Mergendoller and S. Boss. 2015. Setting the Standard for Project-Based Learning: A Proved Approach to Rigorous Classroom Interaction. ASCD: USA. 2015

[5] A. Patton, Work that matters: The teacher guides to project learning. London: Paul Hamlyin Foundation, 2012.

[6] I. Fragoulis, Project-Based Learning in the Teaching of English as A Foreign Language in Greek Primary Schools: From Theory to Practice. Greece: University of Ioannina.English Language Teaching. Vol. 2 Journal. 2009

[7] A. Sudrajat, Lesson Study untuk Meningkatkan Proses dan Hasil Pembelajaran.

https://akhmadsudrajat.wordpress.com/2008/02/22/lesson-studyuntuk-meningkatkan-pembelajaran/

[8] Nurhajati, D and Widiarini, Enhancing Students' SelfConfidence Through Teacher's Behaviour Change on Lesson Study Program For TEYL 1. Proceeding WALS International Conference 2014, pp. 540-545

[9] http://www.walsnet.org/2014/file/WALS\%202014\%20PROCEE DINGS.pdf

[10] J. Howard, J., \& J. Mayor, Guidelines for Designing Effective English Language Teaching Materials. Proceeding of the $9^{\text {th }}$ Conference of Pan-Pacific Association of Applied Linguistic. Japan. Retrieved on 28 Augustus 2015, pp. 103-104. www.paaljapan.org/resources/proceedings/PAAL9/pdf/Howard. pdf 